\title{
PARTISIPASI MASYARAKAT NELAYAN DALAM PENGEMBANGAN BUDAYA WISATA BAHARI DI KABUPATEN AGAM
}

\author{
Lucky Zamzami
}

\begin{abstract}
Tourism area development has always been associated with the empowerment of coastal communities. The coastal communities have a lot of knowledge about the objective region conditions, especially in the area tourism, always used approach to the local community as a model of participatory planning. Economic empowerment of coastal communities through the development of tourism area in Tiku coastal regions is integrated as an attempt ideal to address the issues of economic, social and ecological existing in coastal areas that not ignoring dimensions such as philosophy of empowerment, social-cultural potential of communities based on local wisdom local community.
\end{abstract}

\section{Keywords: Participation, Fishermen Society, Tourism Area, Local Knowledge}

\section{A. PEndahuluan}

$\mathrm{S}$ alah satu model pemberdayaan masyarakat pesisir yang telah dikembangkan secara nasional oleh pemerintah adalah program Pemberdayaan Ekonomi Masyarakat Pesisir (PEMP) pada rentang tahun 2001 hingga 2008. Program ini terbilang sukses dalam pelaksanaannya. Program PEMP dilaksanakan bertujuan untuk meningkatkan kesejahteraan masya rakat pesisir melalui penguatan kelem bagaan sosial ekonomi dengan mendayagunakan sumberdaya laut dan pesisir secara berkelanjutan. Program PEMP ini dimplementasikan hampir di seluruh daerah pesisir secara serentak termasuk di Provinsi Sumatera Barat. Program PEMP yang telah dilaksanakan di Sumatera Barat $^{2}$ meng hasilkan peningkatan kultur kewirausahaan (entrepreneurship), penguatan Lembaga Keuangan Mikro (LKM), peningkatan partisipasi masyarakat pesisir dan kegiatan usaha ekonomi produktif lainnya yang berbasis sumber daya lokal dan berkesinambungan.

${ }^{1}$ Penulis adalah dosen tetap jurusan Antropologi FISIP Universitas Andalas, Padang

- Program PEMP yang dilaksanakan di propinsi Sumatera Barat dilaksanakan di 5 Kabupaten/Kota, yaitu Kabupaten Agam, Pesisir Selatan, Pasaman, Padang Pariaman dan Kota Padang. (Zamzami, Lucky (2011). Pemberdayaan Ekonomi Masyarakat Pesisir di Nagari Amping Perak, Sumatera Barat dalam Jurnal MIMBAR Unisba-Akreditas B Dikti)
Sejalan dengan program pemerintahan JOKOWI-JK saat ini, yaitu "Menjadikan Indonesia menjadi poros maritim dunia" yaitu dengan meningkatkan penguatan pembangunan maritim yang diiringi dengan menguatnya tuntutan demokratisasi dan peningkatan peranan masyarakat (stakeholders), pemerataan dan keadilan serta perhatian terhadap potensi laut dan keanekaragaman daerah, maka proses pengembangan kawasan pesisir dan laut hendaknya disusun dalam bingkai pendekatan integralistik yang sinergistik dan harmonis, dengan memperhatikan sistem nilai dan kelembagaan yang tumbuh dan berkembang dalam masyarakat setempat serta sejalan dengan pengembangan sumber-sumber potensi lokal dan kearifan lokal.

Melalui pembangunan poros maritim dengan mengembangkan wisata bahari di Indonesia harus memanfaatkan Indonesia sebagai Negara Maritim. Potensi maritim ini memiliki prospek besar, salah satunya dalam wisata bahari, sehingga sangat menguntungkan kedepan apabila pariwisata bahari di Indonesia dapat dikembangkan dengan baik dan professional. Pada tahun 2007, Provinsi Sumatera Barat oleh Departemen Kebudayaan dan Pariwisata telah ditetapkan salah satu dari lima daerah di Indonesia yang dijadikan sebagai daerah destinasi unggulan serta menawarkan Mentawai sebagai lokasi selam terbaik Indonesia. Kebijakan ini ditetapkan oleh pemerintah pusat sebagai upaya mengembangkan pariwisata di luar pulau 
Jawa dan Bali.. Hal ini merupakan kesempatan untuk mengembangkan dan mempromosikan potensi wisata, khususnya wisata bahari atau kawasan pesisir yang terdapat di Sumatera Barat. Kawasan pesisir Sumatera Barat memiliki potensi yang luar biasa dan prospek untuk dikembangkan. Selain kekayaan laut yang masih belum tergarap dengan optimal, kawasan-kawasan ini memiliki objek wisata yang bisa dikembangkan secara luas. Berikut adalah potensi wisata bahari Sumatera Barat.

Tabel 1 Potensi Wisata Bahari Sumatera Barat

\begin{tabular}{|c|l|l|}
\hline No & \multicolumn{1}{|c|}{ Kabupaten/Kota } & \multicolumn{1}{c|}{ Objek } \\
\hline 1 & Agam & Pantai Mutiara, Tiku \\
\hline 2 & Pesisir Selatan & $\begin{array}{l}\text { Pantai Carocok, Resort Mandeh, Pulau } \\
\text { Cubadak, Pulau Cingkuak, Semangka Besar } \\
\text { dan Semangka Kecil, Pulau Babi, Pulau Aur } \\
\text { Kecil dan Aur Besar serta Pulau Pagang }\end{array}$ \\
\hline 3 & Kota Padang & $\begin{array}{l}\text { Pantai Air Manis, Pantai Padang, Pantai Pasir } \\
\text { Jambak, Sungai Pisang, Pulau Sikuai, Pulau } \\
\text { Pasumpahan dan Pulau Sao }\end{array}$ \\
\hline 4 & Padang Pariaman & $\begin{array}{l}\text { Pantai Tiram, Pantai Arta, Pantai Gondorian, } \\
\text { Pulau Bando, Pulau Pieh, Pulau Angso, Pulau } \\
\text { Karsik dan Pulau Ujung }\end{array}$ \\
\hline 5 & Pasaman Barat & Air Bangis, Pantai Sasak \\
\hline
\end{tabular}

Sumber: Disbudpar Kota Padang, 2012.

Namun demikian, potensi wisata bahari tersebut belum mampu dikelola dengan baik oleh pemerintah maupun masyarakat. Kawasan pantai yang dimiliki oleh pemerintah Kabupaten/Kota saat ini sangat potensial untuk menjadi kawasan wisata bahari yang akhir-akhir ini telah menjadi salah satu produk wisata yang unggul.

Pemerintah Kabupaten Agam berupaya mengedepankan wisata bahari setelah melihat potensi yang belum dioptimalkan. Hal ini ditunjukkan dengan keseriusan pemerintah Kabupaten Agam di tahun 2013 untuk membenahi kawasan 3 (tiga) pantai yang berada di Kecamatan Tanjung Mutiara, yaitu pantai Muara Batang Tiku, Pantai Bandar Mutiara dan Pulau Ujung dan Tangah. Kawasan wisata bahari yang berada di Pantai Tiku, Tanjung Mutiara, dengan jumlah nelayan sebanyak 2.780 orang, yang terdiri dari nelayan penuh 1.689 orang dan nelayan sambilan 561 orang $^{3}$. Kawasan pesisir Tiku dikenal sebagai sentra perikanan laut dan merupakan salah satu outlet komoditi unggulan perikanan Kabupaten Agam. Kawasan pesisir Tiku merupakan wilayah yang memiliki potensi daya alam laut

\footnotetext{
3 http://komapos.com/Sumbar/Agam/5930pemkab -agam-kembangkan-dua-pulau/17 februari 2015
}

dengan garis pantai sepanjang kurang lebih $6 \mathrm{~km}$ yang pemanfaatannya memiliki potensi wisata bahari belum tergali secara maksimal.

Rencana pengembangan kawasan wisata bahari harus dikaitkan dengan pemberdayaan masyarakat pesisir. Masyarakat pesisir adalah masyarakat yang memiliki banyak pengetahuan tentang kondisi obyektif wilayahnya. Oleh karena itu dalam pengembangan kawasan wisata bahari, senantiasa hendaknya di mulai pendekatan terhadap masyarakat setempat sebagai suatu model pendekatan pe rencanaan partisipatif yang menempatkan masyarakat pesisir memungkinkan saling berbagi, meningkatkan dan menganalisa pengetahuan mereka tentang bahari dan kehidupan pesisir, membuat rencana dan bertindak. Pemberdayaan ekonomi masya rakat pesisir melalui pembangunan kawasan wisata bahari di Kawasan pesisir Tiku secara terpadu diyakini sebagai upaya ideal untuk mengatasi persoalan ekonomi, sosial dan ekologi yang ada pada kawasan pesisir tersebut, dengan tidak mengabaikan dimensi-dimensi seperti filosofi pember dayaan, potensi sosial budaya masyarakat berdasarkan kearifan lokal masyarakat setempat. 


\section{B. Perumusan Masalah}

B erdasarkan latar belakang diatas, maka perumusan masalah penelitian ini adalah sebagai berikut:

1. Bagaimana persepsi pengetahuan, perilaku dan kearifan lokal ma syarakat nelayan mengenai peman faatan potensi sumber daya sosial dan ekonomi untuk mendukung pengembangan budaya wisata bahari di Pantai Tiku, Tanjung Mutiara, Agam?

2. Bagaimana tingkat partisipasi dan keterlibatan masyarakat nelayan terhadap pengembangan kawasan wisata bahari di Pantai Tiku, Tanjung Mutiara, Agam?

\section{Tujuan}

B erdasarkan latar belakang di atas, tujuan khusus dari penelitian ini adalah sebagai berikut:

1. Mendeskripsikan pengetahuan dan perilaku masyarakat nelayan me ngenai pemanfaatan potensi sumber daya sosial dan ekonomi untuk mendukung pengembangan budaya wisata bahari.

2. Mendeskripsikan kearifan lokal masyarakat nelayan terhadap pe ngembangan kawasan wisata ba hari.

3. Mendeskripsikan partisipasi dan keterlibatan masyarakat nelayan terhadap pengembangan kawasan wisata bahari.

\section{Manfaat Penelitian}

K ajian penelitian ini memberikan beberapa sumbangan besar dalam disiplin ilmu Antropologi, khususnya kajian antropologi maritim dan pembangunan masyarakat desa. Studi pemberdayaan ekonomi masyarakat pesisir yang dikaji dapat dikatakan bukanlah merupakan sesuatu hal yang baru dalam masyarakat secara umum. Namun demikian, di satu sisi, pembangunan yang berpusat pada masyarakat lebih menekankan pada pemberdayaan (empowerment) yang memandang potensi masyarakat sebagai sumber daya utama dalam pembangunan dan memandang kebersamaan sebagai tujuan yang akan dicapai dalam proses pembangunan.

\section{E. Metode Penelitian}

$\mathrm{P}$ enelitian ini merupakan penelitian dengan pendekatan kualitatif digunakan metode deskriptif inter pretatif ${ }^{4}$. Pilihan terhadap pendekatan kualitatif ini di dasarkan pada rumusan dan tujuan yang hendak dicapai dalam penelitian ini. $^{5}$. Berdasarkan fenomena yang diteliti, teknik ini mampu membuat model kategorisasi, proposisi dan dalil yang ditemukan guna mengembangkan konsepkonsep baru ${ }^{6}$. Pendekatan kualitatif dilakukan dengan menggunakan data primer, yaitu observasi dan wawancara terstruktur dan data sekunder, yaitu data yang diperoleh sudah diolah, seperti dokumen-dokumen tertulis dan studi kepustakaan. Data sekunder yang dibutuhkan merupakan data mengenai gambaran umum atau deskripsi wilayah penelitian yang dalam hal ini meliputi: (a) Keadaan lingkungan dan keadaan demografis, (b) keadaan ekonomi dan keadaan sosial budaya.

Untuk memperoleh data yang valid dan reliabel maka dipilihlah tehnik yang tepat dan benar. Menurut Vredenbregt ${ }^{\prime}$, teknik umum yang digunakan dalam studi kasus adalah observasi langsung, observasi partisipasi dan wawancara bebas. Tetapi dalam penelitian ini digunakan tehnik wawancara bebas (interview) sebagai tehnik umum dengan maksud untuk menjaga data

${ }^{4}$ Denzim Norman K. and Yvonna S. Lincoln (ed), (1994), Handbook of Qualitative Research, USA: Sage Publications hal 266

${ }^{5}$ Lawrence Neuman, W. (1997), Social Research Methods: Qualitative and quantitative approaches. London: Allyn and Bacon hal 15-18 6 Earl Babbie, 1983. The Practice of Social Research. Belmont, California: Wadsworth Publishing Company. Baca juga Lawrence Neuman, W. (1997), Social Research Methods: Qualitative and quantitative approaches. London: Allyn and Bacon, Denzim Norman K. and Yvonna S. Lincoln (ed), (1994), Handbook of Qualitative Research, USA: Sage Publications

Vredenbregt, (1983), Metode dan Teknik Penelitian Masyarakat, Jakarta: PT. Gramedia hal 72-90 
primer yang relevan terhadap setiap variabel penelitian maka wawancara yang akan dilakukan didasarkan pada pedoman wawancara yang berisikan pertanyaan terbuka (open ended question), dengan demikian diharapkan informan dapat menjawab dengan leluasa dan bebas dalam memberikan berbagai alternatif jawaban.

Kabupaten Agam dipilih menjadi lokasi penelitian ini berdasarkan upaya Pemda mengedepankan wisata bahari setelah melihat potensi kawasan 3 (tiga) pantai yang berada di Kecamatan Tanjung Mutiara, yaitu pantai Muara Batang Tiku, Pantai Bandar Mutiara dan Pulau Ujung dan Tangah menjadi kawasan wisata bahari yang berada di Pantai Tiku, Tanjung Mutiara.
Pemilihan informan diambil secara purposive (sengaja), dimana pengambilan informan yang bersifat tidak acak dan juga berdasarkan pertimbangan-pertimbangan tertentu yang dapat memberikan informasi sesuai dengan masalah yang diteliti. Saat penelitian berlangsung, pemilihan informan dibagi ke dalam dua, yaitu informan kunci dan informan biasa. Informan kunci yang telah dipilih adalah nelayan yang tergabung dalam 5 kelompok nelayan yang memiliki partisipasi yang aktif dalam kegiatan kelautan dan perikanan. Sedangkan informan biasa adalah pejabat pemerintahan kecamatan dan nagari dan tokoh-tokoh masyarakat. Berikut ini daftar informan yang berhasil diwawancarai.

Tabel 2. Daftar Informan yang Berhasil Diwawancarai Dalam Penelitian

\begin{tabular}{|c|l|l|l|}
\hline No. & \multicolumn{1}{|c|}{ Nama Informan } & \multicolumn{1}{c|}{ Umur } & \multicolumn{1}{c|}{ Pekerjaan } \\
\hline 1 & Joheri & 50 Tahun & Sekretaris Camat \\
\hline 2 & Zalwirman & 50 Tahun & Nelayan/Kepala Jorong \\
\hline 3 & Roni Panungkek & 45 Tahun & Ketua Pokwasmas \\
\hline 4 & Karmani & 39 Tahun & Isteri Nelayan \\
\hline 5 & Bareh & 66 Tahun & Nelayan \\
\hline 6 & Ilham & 55 Tahun & Nelayan \\
\hline 7 & Wati & 47 Tahun & Isteri Nelayan \\
\hline 8 & Ida & 33 Tahun & Isteri Nelayan \\
\hline 6 & Fatmawati & 50 tahun & Isteri Nelayan \\
\hline 7 & Herlinda & 45 Tahun & Sekretaris Nagari \\
\hline
\end{tabular}

Sumber: Data Primer Penelitian, 2015.

Analisa data dikumpulkan oleh peneliti termasuk juga catatan lapangan dikelompokkan oleh peneliti atas dasar aktivitas khusus yang ada dan diteliti. Kemudian dari pengelompokkan data tersebut, data-data itu kemudian diabstrak sikan dan dikaitkan satu dengan lainnya sebagai satu kesatuan kejadian dan fakta yang terintegrasi. Dari abstraksi tersebut maka akan tampak pranata sosial yang berlaku di wilayah atau komuniti tersebut (Bungin, 2004:60). Dalam menganalisis tentunya selalu terkait dengan konsep yang telah dipelajari sebelumnya. Sehingga dari hasil analisis akan tampak kesesuaian dari data yang diperolehnya dengan konsep yang dipelajarinya atau akan berbeda dengan konsep yang dipelajarinya karena masalah sosial akan selalu berbeda antara satu masyarakat dengan masyarakat lainnya. Setelah itu disusun sesuai dengan kategori-kategori dan kemudian disimpulkan. Apabila dalam kesimpulan masih menimbulkan keraguan maka dilakukan pengkategorian ulang hingga seluruh data yang telah berhasil dikumpulkan dianggap sesuai dengan tujuan penelitian. Temuan di lapangan akan diolah dengan data yang didapat dari literatur dan akan disajikan dalam suatu karya etnografi deskriptif.

\section{F. KAJIAN PUSTAKA 1. Paradigma Ekonomi Masyarakat}

$\mathrm{K}$ ebutuhan lain masyarakat yang selama ini tidak dipenuhi, yaitu kurang dilibatkannya masyarakat pesisir dalam pembangunan. Keterlibatan yang dimaksudkan di sini adalah keterlibatan secara total dalam semua aspek program pembangunan yang menyangkut diri mereka, yaitu sejak perencanaan program, pelaksanaannya, evaluasinya, serta perelevansiannya. Dengan kata lain, kekurangan yang dimiliki selama ini yaitu 
tidak atau kurang partisipasi masyarakat dalam pembangunan diri mereka sendiri. Padahal partisipasi itu begitu perlu karena bagaimanapun juga, dan dengan dengan segala jenis upaya, tidak ada seorang miskinpun yang bisa keluar dari kemiskinannya dengan bantuan orang lain, bila dia tidak membantu dirinya sendiri. Di Sri Lanka, misalnya, pembangunan untuk mengatasi kemiskinan nelayan begitu signifikan hasilnya karena prinsip program pembangunan yang dianut adalah helping the poor to help themselves ${ }^{8}$.

\begin{tabular}{lrr} 
& \multicolumn{2}{c}{ Program pemberdayaan masyarakat } \\
telah menjadi & mainstream & upaya \\
peningkatan & kesejahteraan & serta \\
pengengentasan & kemiskinan. & Dengan \\
pemberdayaan & masyarakat & maka
\end{tabular}
pembangunan tidak mulai dari titik nadir, tetapi berawal dari sesuatu yang sudah ada pada masyarakat. Pemberdayaan berarti apa yang telah dimiliki oleh masyarakat adalah sumberdaya pembangunan yang perlu dikembangkan sehingga makin nyata kegunaannya bagi masyarakat sendiri.

Paling tidak ada lima pendekatan pemberdayaan masyarakat pesisir yang baru saja diimplementasikan. Dengan adanya kelima pendekatan ini tidak berarti bahwa pendekatan lain tidak ada. Selama ini, baik lingkup Departemen Kelautan dan Perikanan maupun instansi pemerintah lainnya, pemerintah daerah, dan khususnya lembaga swadaya masyarakat dalam bentuk yayasan dan koperasi telah banyak yang melakukan kegiatan pemberdayaan masyarakat. Kelima pendekatan tersebut adalah: (1) penciptaan lapangan kerja alternatif sebagai sumber pendapatan lain bagi keluarga, (2) mendekatkan masyarakat dengan sumber modal denganpenekanan pada penciptaan mekanisme mendanai diri sendiri (self financing mechanism), (3) mendekatkan masyarakat dengan sumber teknologi baru yang lebih berhasil dan berdaya guna, (4) mendekatkan masyarakat dengan pasar, serta (5) membangun solidaritas serta aksi kolektif di tengah masyarakat. Kelima pendekatan ini dilaksanakan dengan memperhatikan secara sungguh-sungguh aspirasi, keinginan, kebutuhan, pendapatan, dan

8 BOBP. (Bay of Bengal Program). 1990. Helping Fisherfolk to Help Themselves. A Study in People's Participation. BOBP. 182 p. potensi sumberdaya yang dimiliki masyarakat. Pemberdayaan masyarakat secara khusus dan eksistensi masyarakat secara umum perlu diinternalisasikan dalam pengembangan, perencanaan, serta pelaksanaan pengelolaan sumberdaya pesisir secara terpadu. Beberapa aspek yang berkenan dengan masyarakat adalah kekuatan penentu (driving forces) status dan eksistensi suatu kawasan pesisir. Kekuatan tersebut perlu dilibatkan atau diperhitungkan dalam menyusun konsep pengelolaan sumberdaya secara terpadu? .

Pemberdayaan masyarakat nelayan dan pembangunan kawasan pesisir secara terpadu masih diyakini sebagai upaya ideal untuk mengatasi berbagai persoalan sosial, ekonomi dan lingkungan yang menumpuk di kawasan pesisir. Kunci keberhasilan program pembangunann untuk membebaskan masyarakat pesisir dari berbagai jerat kehidupan tersebut bertumpu pada kemampuan sumber daya lokal, berorientasi membangun kemandirian internal masyarakat, adanya dukungan kebijakan yang konsisten dari pemerintah dan keterlibatan pihak-pihak lain untuk mendorong dinamika pembangunan kawasan atas dasar tanggung jawab bersama, kepedulian sosial dan bersifat menguntungkan bagi semua pihak secara berkelanjutan $^{10}$.

$$
\text { Pemberdayaan }
$$

ekonomi masyarakat pesisir ini bisa dikatakan sebagai suatu program usaha perikanan terpadu, mulai dari tahapan perencanaan, pelaksanaan hingga evaluasi. Keterpaduan juga terwujud dalam hal kegiatan ekonomi produktif yang dilakukan masyarakat yang memang tidak terfokus pada kegiatan tertentu namun tersebar ke dalam kelompok kegiatan yang saling terkait. Demikian pula keterpaduan diwujudkan melalui pelibatan stakeholder yang berasal dari berbagai

\footnotetext{
9 Victor P.H. Nikijuluw. 2001. Populasi dan Sosial Ekonomi Masyarakat Pesisir serta Strategi Pemberdayaan Mereka Dalam Konteks Pengelolaan Sumberdaya Pesisir Secara Terpadu dalam Makalah pada Pelatihan Pengelolaan Pesisir Terpadu. Proyek Pesisir, Pusat Kajian Sumberdaya Pesisir dan Lautan, Institut Pertanian Bogor (IPB). Hotel Permata, Bogor, 29 Oktober 2001

10 Kusnadi, 2006. Filosopi Pemberdayaan Masyarakat Pesisir. Bandung: Humaniora.
} 
pihak, instansi pemerintah, masyarakat dan swasta.

\section{Pengetahuan dan Perilaku \\ Pengetahuan adalah}

hasil

penginderaan manusia, atau hasil tahu seseorang terhadap objek melalui indera yang dimilikinya (mata, hidung, telinga, dan sebagainya). Dengan sendirinya, pada waktu penginderaan sampai menghasilkan pengetahuan tersebut sangat dipengaruhi intensitas perhatian dan persepsi terhadap objek. Sebagian besar pengetahuan seseorang diperoleh melalui indera pendengaran (telinga), dan indera penglihatan (mata). ${ }^{11}$ Pengetahuan itu sendiri dipengaruhi oleh faktor pendidikan formal. Pengetahuan sangat erat hubungannya dengan pendidikan, dimana diharapkan bahwa dengan pendidikan yang tinggi maka orang tersebut akan semakin luas pula pengetahuannya. Akan tetapi perlu ditekankan, bukan berarti seseorang yang berpendidikan rendah mutlak berpengetahuan rendah pula. Pengetahuan seseorang tentang suatu objek mengandung dua aspek, yaitu aspek positif dan negatif. Kedua aspek ini yang akan menentukan sikap seseorang semakin banyak aspek positif dan objek yang diketahui, maka akan menimbulkan sikap makin positif terhadap objek tertentu.

Pengetahuan dinyatakan sebagai informasi yang diketahui atau disadari oleh seseorang. Pengetahun adalah berbagai gejala yang ditemui dan diperoleh manusia melalui pengamatan akal. Pengetahuan muncul ketika seseorang menggunakan akl budinya untuk mengenal benda atau kejadian tertentu. Oleh karena pengetahun merupakan informasi yang sudah dikombinasikan dengan pemahaman dan potensi untuk menindaki maka pengetahuan mempunyai sifat prediktif terhadap sesuatu sebagai hasil pengenalan atas suatu pola dan mempunyai kemampuan untuk mengarahkan tindakan. ${ }^{12}$

\section{Kearifan Lokal}

11 Notoatmodjo, s. 2003. Pendidikan dan perilaku kesehatan, Jakarta : PT Rineka Cipta

12 http://id.Wikipedia.org/pengetahuan, diakses tanggal 20 April 2015
Kearifan lokal muncul sebagai penjaga atau filter iklim global yang melanda kehidupan manusia. Kearifan adalah proses dan produk budaya manusia, dimanfaatkan untuk mempertahankan hidup. Kearifan lokal adalah bagian dari budaya. Kearifan lokal lebih menekankan pada tempat dan lokalitas dari kearifan tersebut sehingga tidak harus merupakan sebuah kearifan yang telah diwariskan dari generasi ke generasi. Kearifan lokal bisa merupakan kearifan yang belum lama muncul dalam suatu komunitas sebagai hasil dari interaksinya dengan lingkungan alam dan interaksinya dengan masyarakat serta budaya lain. Oleh karena itu, kearifan lokal tidak selalu bersifat tradisional karena dia dapat mencakup kearifan masa kini, dan karena itu pula bisa lebih luas maknanya daripada kearifan tradisional.

Dari sisi filosofi dasarnya, kearifan dapat dikategorikan dalam dua aspek, yaitu: (a) gagasan, pemikiran, akal budi yang bersifat abstrak; dan (b) kearifan lokal yang berupa hal-hal konkret, dapat dilihat. Kearifan lokal kategori (a) mencakup berbagai pengetahuan, pandangan, nilai serta praktik-praktik dari sebuah komunitas baik yang diperoleh dari generasi sebelumnya dari komunitas tersebut maupun yang didapat oleh komunitas tersebut di masa kini, yang tidak berasal dari generasi sebelumnya, tetapi dari berbagai pengalaman di masa kini, termasuk juga dari kontaknya dengan masyarakat atau budaya lain. Kearifan lokal kategori (b) biasanya berupa benda-benda artefak, yang menghiasi hidup manusia, dan bermakna simbolik. Dalam setiap jengkal hidup manusia selalu ada kearifan lokal. Paling tidak, kearifan dapat muncul pada: (a) pemikiran, (b) sikap, dan (c) perilaku. Ketiganya hampir sulit dipisahkan. Jika ketiganya ada yang timpang, maka kearifan lokal tersebut semakin pudar. ${ }^{13}$

\section{G. PEMBAHASAN HASIL PENELITIAN}

13 Ataupah, 2004, Peluang Pemberdayaan Keraifan Lokal Dalam Pembangunan Kehutanan, Kupang. 
a. Gambaran Demografi, Sosial dan Ekonomi Masyarakat Nelayan Tiku

$\mathrm{N}$ agari Tiku Selatan terletak di Kecamatan Tanjung Mutiara, Kabupaten Agam, Sumatera Barat. Nagari Tiku Selatan terdiri dari 7 jorong, yang terdiri: (1) Jorong Gasan Kaciak dengan luas wilayah $1.141 \mathrm{Ha}$; (2) Jorong Banda Gadang dengan luas wilayah 724 $\mathrm{Ha}$; (3) Jorong Pasa Tiku dengan luas wilayah $111 \mathrm{Ha}$; (4) Jorong Pasia Tiku dengan luas wilayah $100 \mathrm{Ha}$; (5) Jorong Kampung Darek dengan luas wilayah $520 \mathrm{Ha}$; (6) Jorong Pasia Paneh dengan luas wilayah $605 \mathrm{Ha}$; dan (7) Jorong Sungai Nibuang dengan luas wilayah 385 $\mathrm{Ha}$.

Jumlah jorong yang berada di daerah pesisir sebanyak 4 buah $(21 \%)$ dan jorong bukan pesisir sebanyak 15 buah (79\%), dengan jumlah penduduk pesisir dengan mata pencaharian sebagai nelayan sebanyak 2.152 KK (2\%). Nagari Tiku Selatan berbatasan sebelah utara dengan Nagari Tiku V Jorong, sebelah Selatan dengan Nagari Batang Gasan, sebelah Barat berbatasan dengan Samudra Indonesia dan sebelah Timur berbatasan dengan Nagari Tiku Utara.

Nagari Tiku Selatan memiliki ketinggian tempat berkisar $2 \mathrm{~m}$ dari permukaan laut dengan suhu rata-rata sekitar $26^{\circ} \mathrm{C}_{-} 30^{\circ} \mathrm{C}$ dengan rata-rata curah hujan $2000 \mathrm{~mm}$. Wilayah ini terdiri dari dataran rendah, dengan tinggi pesisir pantai yang rendah. Berdasarkan penggunaan lahan dan luas wilayah menjelaskan bahwa penggunaan lahan perumahan dan lahan persawahan yang memiliki aliran irigasi mendominasi luas wilayah di Nagari Tiku Selatan, Kecamatan Tiku Selatan, Kabupaten Agam. Nagari Tiku Selatan memiliki garis pantai yang cukup panjang dan juga memiliki keindahan dari aspek pemandangan lautnya.

Berdasarkan data kependudukan Nagari Tiku Selatan tahun 2012, jumlah penduduk sebanyak 13.003 jiwa orang, dengan penduduk laki-laki berjumlah 6.699 jiwa dan penduduk perempuan 6.304 jiwa orang. Jumlah kepala keluarga (KK) adalah 2.608. Berdasarkan hasil wawancara diperoleh bahwa jumlah penduduk terbanyak di Nagari Tiku Selatan yang dikategorikan pada usia produktif berada pada tingkat umur antara 20 tahun hingga 50 tahun. Hal tersebut terkait erat dengan berbagai pekerjaan yang ditekuni oleh masyarakat di Nagari Tiku Selatan.

Bahwa sebagian besar penduduk di Nagari Tiku Selatan bermata pencaharian sebagai petani, buruh dan nelayan, terutama nelayan buruh sebanyak $145(11 \%)$. Salah satu penyebabnya adalah kondisi wilayah Nagari Tiku Selatan yang terletak memanjang di garis pantai daerah Nagari Tiku Selatan. Kesadaran masyarakat di Nagari Tiku Selatan terhadap pentingnya pendidikan cukup tinggi dimana sebagian besar masyarakatnya sudah mengenyam pendidikan padan tingkat SMP dan SMA. Meskipun demikian, sebagian masyarakatnya juga ada yang menamatkan pendidikan hanya pada tingkat SD. Bahwa tingkat pendidikan di Nagari Tiku Selatan sudah cukup tinggi. Hal tersebut diperlihatkan melalui jumlah penduduk yang telah menamatkan pendidikan SD, SMP, SMA dan perguruan tinggi sebanyak 6.350 (90\%). Meskipun demikian, diperoleh juga terdapat penduduk yang tidak menamatkan pendidikan SD $(10 \%)$. Pada umumnya, mereka yang tidak menamatkan pendidikan SD dikarenakan faktor ekonomi dan kesempatan. Untuk menunjang aktivitas pendidikan masyarakat di Nagari Tiku Selatan sangat dibutuhkan sarana dan prasarana agar tujuan pendidikan dapat tercapai. Jumlah sarana pendidikan di Nagari Tiku Selatan cukup memadai dengan tersedianya sarana pendidikan SMP dan SMA. Hal tersebut diperlihatkan dari tingkat pendidikan yang cukup tinggi dengan tingkat pendidikan SMP dan SMA.

Pola pemukiman adalah wujud dari bentuk pemukiman pada suatu daerah yang meliputi pola letak tempat tinggan dan bentuk rumah di pemukiman tersebut. Pola letak pemukiman di Nagari Tiku Selatan tidak berbeda jauh dengan pola pemukiman wilayah pesisir di daerah lain, dimana rumah-rumah membentang sepanjang pantai di pesisir pantai Tiku. Pola pemukiman Nagari Tiku Selatan yang mengikuti garis pantai dimulai dari Jorong Gasan Kaciak , kemudian dilanjutkan menuju Jorong Banda Gadang, Jorong Pasa Tiku dan Jorong Pasia Tiku. Untuk 3 
jorong lainnya berada di sepanjang perbukitan yang berada di seberang garis pantai. Untuk menuju Nagari Tiku Selatan, dapat ditempuh dengan kendaraan beroda dua dan empat dengan sarana jalan yang cukup baik sehingga dapat ditempuh selama 1.5 jam perjalanan dari ibu kota Sumatera Barat, yaitu kota Padang.

Kepemilikan rumah yang berada di sekitar pantai adalah sebagian besar dimiliki oleh rumah tangga nelayan buruh dan juga pedagang ikan berskala kecil. Pada umumnya, bentuk rumah di Nagari Tiku Selatan, terutama kampung-kampung di sekitar pantai terdiri dari rumah tidak permanen dan semi permanen dan hanya beberapa rumah saja yang permanen, yaitu sekitar 5-10 rumah. Untuk rumah-rumah yang berada di sekitar jalan utama yang menghubungkan antar jorong di Nagari Tiku Selatan, keadaannya lebih baik dari rumah yang ada di dekat pantai. Biasanya rumahrumah di wilayah ini dihuni oleh pedagang ikan dengan skala yang lebih besar dibandingkan dengan pedagang yang ada di pinggir pantai.

Berdasarkan observasi (melalui pengamatan), terdapat beberapa rumah di pemukiman sekitar wilayah pantai (5-10 rumah) yang dihuni oleh para nelayan yang tidak layak untuk menjadi tempat tinggal. Rumah mereka hanya beralaskan pasir pantai dan berdindingkan kayu dan juga atapnya terbuat dari seng yang sudah berkarat dan berlubang. Di sekitar pemukiman nelayan, terdapat 2-4 warung makanan yang selalu dipenuhi oleh para nelayan buruh, terutama sekali ketika mereka sudah selesai melaksanakan aktivitas penangkapan ikan seperti memukat dan juga pada saat terjadinya badai (cuaca tidak baik). Aktivitas yang biasa mereka lakukan adalah berdiskusi tentang aktivitas penangkapan ikan, bermain domino/kartu dan hanya sekedar minum kopi.

Aktivitas ekonomi perikanan yang dilakukan oleh nelayan pada umumnya dilakukan secara berkelompok tetapi ada juga yang melakukannya secara perorangan. Kegiatan tersebut sebagian besar dilakukan oleh pihak laki-laki yang berumur diatas 15 tahun. Pendapatan nelayan di nagari Tiku Selatan berkisar antara Rp.25.000,- hingga Rp. 100.000,-Pendapatan nelayan termasuk rendah dikarenakan sebagian besar nelayan di nagari Tiku Selatan tersebut adalah nelayan buruh (60\%). Aktivitas penangkapan ikan pada masyarakat nelayan Nagari Tiku Selatan, yaitu aktivitas membagan, memayang, memukat dan menjaring. Teknologi pada penangkapan ikan menjaring menggunakan peralatan jaring dan perahu. Jaring yang selalu dipergunakan oleh masyarakat nelayan Nagari Tiku Selatan adalah yang berukuran 100-200 m. Jaring ini ada yang jahitannya halus dan kasar. Jaring yang halus ukuran matanya memiliki panjang 25-20 cm dan lebarnya kira-kira $5 \mathrm{~cm}$, sedangkan jaring yang jahitannya kasar ukuran matanya memiliki panjang 50-60 cm dan lebar $10 \mathrm{~cm}$. Untuk jahitan yang kasar adalah untuk menangkap ikan yang besar-besar seperti ikan gembolo, ikan gurigak, belatuk dan soaso, sedangkan jahitan yang halus atau rapat adalah untuk menangkap ikan yang kecil-kecil seperti ikan campu, pinangpinang, maco dan tete. Untuk menangkap ikan dengan menjaring mempergunakan sebuah perahu yang panjangnya lebih kurang $4 \mathrm{~m}$ dan lebarnya $1 \mathrm{~m}$. Perahu yang banyak digunakan oleh masyarakat nelayan Nagari Tiku Selatan saat ini sudah banyak memakai mesin perahu/mesin tempel.

Hasil tangkapan ikan yang diperoleh langsung di bawa ke pasar tradisional Tiku Selatan dan disana sudah ada agen atau pembeli yang menanti. Biasanya agen-agen tersebut telah ditentukan oleh induk semang. Alasan lain nelayan menjual ikan di pasar tradisional Tiku Selatan karena semua jenis ikan dapat diterima baik besar maupun kecil, begitu juga dengan jenis-jenisnya.

Nagari Tiku Selatan merupakan Nagari yang memiliki potensi sumber daya alam yang cukup banyak dilihat dari berbagai aspek seperti Nagari Tiku Selatan mempunyai wilayah laut yang dengan garis pantai sepanjang $\pm 6 \mathrm{~km}$ dan disertai dengan Tempat Pendaratan Ikan (TPI) beserta fasilitas penunjang lainnya. Potensi hasil laut nagari Tiku Selatan telah menjadi salah satu andalan ekonomi yang utama dari nagari Tiku Selatan.

\begin{tabular}{llll}
\multicolumn{3}{c}{ Kelompok-kelompok nelayan yang } \\
dibentuk terbagi ke dalam 5 \\
pengelompokkan
\end{tabular} pengelompokkan kelembagaan, yaitu kelompok penangkapan ikan, pengolahan ikan, budidaya ikan lele, kelompok usaha 
bersama dan kelompok pengawas masyarakat. Keterbatasan potensi serta modal usaha nelayan di Nagari Tiku Selatan yang memiliki pengertian nelayan yang bekerja dengan alat tangkap milik orang lain. Mereka harus membagi hasil tangkapannya dengan nelayan juragan (yang memiliki peralatan) sampai $65 \%$ dengan pembagian $50 \%$ untuk nelayan juragan dan $15 \%$ untuk mengatasi kerusakan.

Aktivitas penangkapan ikan yang dilakukan oleh nelayan Nagari Tiku Selatan hampir sama dengan aktivitas penangkapan ikan lainnya di berbagai daerah di wilayah pantai Barat Sumatera. Aktivitas penangkapan ikan yang dilakukan oleh nelayan buruh di wilayah pesisir pantai Selatan Sumatera Barat adalah membagan, memayang, memukat, menjaring dan memancing (Zamzami,2008,2009).

Salah satu faktor penting dalam aktivitas nelayan Nagari Tiku Selatan adalah menjual hasil penangkapan ikan. Hasil produksi berupa ikan yang telah ditangkap di laut oleh nelayan buruh merupakan produksi ikan yang cepat rusak sehingga harus segera dipasarkan. Kondisi ini menyebabkan para nelayan buruh menjual hasil tangkapannya secepatnya setelah berlabuh di tepi pantai. Biasanya hasil tangkapan para nelayan buruh akan langsung dijual di pinggir pantai, dimana di tempat tersebut telah menunggu para pedagang (toke') dan juga pengolah ikan untuk membeli hasil tangkapan mereka. Dalam proses penjualan ikan tersebut, nelayan buruh langsung berhubungan dengan para pedagang atau pengolah ikan tanpa ada perantara.

Untuk aktivitas penangkapan ikan di Nagari Tiku Selatan, terdapat hari di mana para nelayan buruh tidak diperbolehkan melaut, yaitu pada hari jum'at. Pada hari Jum'at tersebut para buruh nelayan hanya fokus beribadah (shalat Jum'at) terutama bagi yang laki-laki dimana kalau ada yang melanggar maka nelayan buruh yang melakukan akan mendapatkan sanksi sosial seperti cemoohan dari masyarakat. Kemudian saat ada kematian, buruh nelayan harus melayat ke rumah jenazah dan mengikuti proses- proses upacara kematian sebagai penghormatan kepada orang yang sudah meninggal.
Biasanya para nelayan Nagari Tiku Selatan ketika ke laut dilakukan pada pagi hari sekitar pukul 06.30 Wib, kemudian kembali pada pukul 16.00 Wib. Kegiatan tersebut dikatakan tidak menentu dimana tergantung kepada hasil tangkapan ikan. Untuk melakukan penangkapan ikan pada malam hari, tidak banyak dilakukan oleh para nelayan buruh dikarenakan kondisi fisik nelayan buruh dan penggunaan perahu sebatas payang dan perahu tanpa mesin.

\section{b. Pengetahuan dan Perilaku Masyarakat Nelayan Untuk Mendukung Pengembangan Budaya Wisata Bahari.}

$\mathrm{P}$ ada kawasan pantai wisata pasia Tiku Kabupaten Agam ini, telah dibentuk Kelompok Masyarakat Pengawas (Pokmaswas), yang terdiri dari lebih kurang 17 orang anggota, dengan struktur organisasi terdiri dari Ketua, Sekretaris, bendahara dan bidang kelengkapan danbidang lapangan. Kelompok ini merupakan perwakilan masyarakat yang terdiri dari pemuda, Ninik-mamak dan masyarakat nagaria Pasia Tiku.

Pada kawasan ini, Kelompok

Pokmaswas telah menetapkan beberapa aturan diantaranya seperti; penjualan di sepanjang pantai pasia Tiku harus berdasarkan harga yang disepakati bersama, dibolehkan kegiatan memancing, dilarang menggunakan peralatan pukat harimau, dilarang melabuhkan jangkar di sekitar kawasan pantai pasia, melaksanakan kegiatan pesta pantai pada waktu sebelum puasa dan setelah lebaran. Meskipun belum dibentuk pengawas pantai oleh pemerintah, namun kelompok ini secara tidak langsung telah bekerja menjadi pengaman masyarakat sekitar. Hal ini terlihat kegiatan mereka melindungi kawasan tersebut dari penangkapan ikan besar dari kalangan kapal-kapal asing atau pengusaha kaya yang menggunakan peralatan yang lebih canggih dan modern. Biasanya mereka akan berkoordinasi dengan pihak DKP pusat melalui sms, Camat, dan DKP Provinsi dan Daerah. Kemudian ditindak lanjuti 
oleh tim DKP (terdiri dari Airut, Pol Air, BNPB, Regu DKP), untuk menangkap kapal tersebut.

Kelompok

Pokmaswas merupakan lembaga masyarakat yang telah diberdayakan masyarakat yang telah dikenalkan dengan pemahaman hukum kelautan dan pantai, hidup bergotong royong dan telah memperoleh hubungan langsung dengan pihak DKP pusat jakarta secara cepat dan efektif. Pada saat mereka melakukan pengawasan terhadap pantai, disamping telah berkoordinasi dengan aparat berwenang, mereka juga melakukan pengawasan harian bahkan melakukan tindakan penanggulangan secara kelompok dengan peralatan seadanya. Meskipun demikian, hal merupakan bentuk kekesalan masyarakat terhadap kenakalan pengusaha asing yang menangkap ikan dengan cara merusak, masif dan menghancurkan terumbu karang dan sumber ikan mereka. Akhirnya masyarakat beramai-ramai (sekitar 30 orang dengan 3 bot) menjarah kapal yang tidak patuh dengan hukum yang telah ditetapkan bersama. Kegiatan ini selalu mereka awasi pada saat gelap tiba hingga pagi hari.

\begin{tabular}{cc}
\multicolumn{2}{c}{ Kesadaran dan pemahaman } \\
mereka terhadap
\end{tabular} melestarikan trumbu karang dan sumber daya ikan telah ada, hal ini terbukti dengan kuatnya kelompok ini yang merupakan kelompok sosial non profit oriented tanpa mengharapkan uang tapi mampu memperkuat kesatuan masyarakat bersama untuk menjaga keamanan dan kelestarian lingkungan sosial dan alam. Mereka telah mengenal jenis peralatanperalatan yang mampu merusak lingkungan alam dan jenis bom perusak lingkungan dan ikut berpartisipasi dalam menjaga pantai dengan semanat: "senasib dan sepenanggungan". Meskipun belum semua anggota kelompok yang mengikuti pelatihan dan pemberdayaan masyarakat, Kelompok ini telah mengenal pelatihan pelanggaran hukum laut, cara bertindak atau prosedur terhadap pelanggaran, hak dan kewajiban mereka terhadap pelangaran hukum laut dan sadar hukum terhadap kelestarian lingkungan laut dan pantai.

\section{c. Kearifan Lokal Masyarakat Nelayan Terhadap Pengembangan Kawasan Wisata Bahari.}

awasan ini yang terdiri dari 3 pulau

1 (pulau tepi/ pantai, pulau ujung, dan pulau tengah) terlihat indah. Dalam perkembangan zaman, tanpa adany koordinasi dari siapapun masyarakat pasia Tiku selalu beramai-ramai menjadi pengunjung di pantai ini terutama sebelum puasa. Maka pimpinan setempat mempertimbangkan hal ini dengan menyambutnya berupa kegiatan "pesta pantai". Dengan dukungan pemda provinsi dan kabupaten kegiatan ini selalu didukung hingga kini. Seiring waktu berjalan, potensi pulau tengah dan pulau ujung seperti di sore hari semnjak adanya penaman pohon cemera oleh $\mathrm{UBH}$, semakin indah, bahkan pengunjung semakin ramai di hari lubur. Atas kesepakatan bersama dibuatlah "pesta nelayan".

Pesta nelayan di pantai merupakan salah satu kearifan lokal bagi masyarakat pasia Tiku dalan dilaksanakan selama sehari sebelum ramadahan dan di hari Senin. Hari ini diambil karena hari pasar bagi masyarakat Tiku. Pada saat itu lah banyak muncul pedagang makanan dari kalangan masyarakat pasia Tiku untuk mendapat keuntungan Pada saat acara ini berlangsung menggunakan musik, dan diresmikan langsung oleh pemda Agam serta dikawal oleh aparat keamanan setempat hingga selesai. Kelompok muda membagi tugas sesuai dengan tanggungjawab dan kesepakatan yang telah sepakati, seperti bidang parkir, kebersihan, peralatan, keamanan, pengawas dan lainnya.

Pesta Pantai diadakan selama 1 hari, dengan harga karcis mulai dari Rp.3000,- hingga Rp.5.000,-. Hasil pesta pantai disumbangkan untuk pembangunan mesjid dan 
mushola. Selain itu dana pesta pantai digunkan untuk pengelolaan kebersihan. Pesta ini menggunakan dua jalur yang dapasangi sekat sepanjang pantai, yang merupakan kawasan tertup pada saat pesta pantai dilaksanakan bagi pengunjung. Selain itu pada pesta tersebut juga mengutamakan masyarakat setempat dengan menggratiskan masyarakat sekitar (memiliki hubungan sekampung).

Selain itu di kawasan pantai ini telah dibentuk himbauan bersama kepada seluruh masyarakat dan para pedagang agar mengosongkan tempat pantai semenjak jam 18.00 Wib sampai pagi. Himbauan ini bertujuan untuk menjaga dan mengawasi pemuda dan kawasan mereka dari perbuatan asusila atau perbuatan mesum. Himbauan ini disampaikan oleh ninik mamak, pemuda dan jajaran pengurus jorong dari warung ke warung, agar di patuhi. Hingga saat ini atauran tersebut masih dipatuhi oleh masyarakat sekitar.

Persoalan yang mencolok di sekitar pantai ini adalah persoalan sampah yang bertumpuk tapi tidak adanya pengelolaan yang baik mulai dari pengumpulan hingga pembungan, sehingga sampahsampah yang ada disekitar area ini bertumpuk pada lingkaran-lingkaran sampah yang sembaraut. Pemandangan ini lebih memperburuk pemandangan kawasan wisata pantai pasia Tiku.

\section{d. Partisipasi Dan Keterlibatan Masyarakat Nelayan Terhadap Pengembangan Kawasan Wisata Bahari.}

$\mathrm{B}$ erdasarkan hasil wawancara bersama Sekretaris Camat, Juheri (50 Tahun) bahwa masyarakat nelayan sering terlibat dalam kegiatan pemberdayaan masyarakat. Salah satunya adalah dari dinas kelautan. Beberapa program yang terlaksana dalam pemberdayaan masyarakat pengawas pantai adalah: Jangka panjang: program transplantasi karang, pendirian rumah singgah untuk nelayan di pulau tangah dalam waktu 3 tahun dan Jangka pendek: penyebaran bibit ikan kerapu sebanyak 15 ribu ekor. Kawasan pantai pasia, meliputi pulau ujuang, pulau pasia, dan pulau tangah. Program kegiatan yang dilaksanakan oleh dinas kelautan berupa transplantasi trumbu karang,

Pada kawasan ini telah dibangun rambu-rambu peringatan, seperti dilarang berenang, petunjuk arah kawasan, himbauan terhadap pusaran air, fasilitas duduk, fasilitas makan, tempat berjualan dan lainnya. Kawasan wisata ini merupakan tanah ulayat milik masyarakat jorong pasia Tiku kabupaten Agam. Kawasan ini terdiri dari Kawasan pantai pasia, meliputi ;pulau pasia (kawasan pantai/ pinggir laut) yang dimiliki oleh ulayat, pulau ujuang (dimiliki oleh masyarakat Sikumbang), dan pulau tangah (dimiliki oleh masyarakat Mandailiang). Beberapa program kegiatan yang mereka lakukan melibatkan dari berbagai pihak, baik pemerintah maupun kalangan akademisi. Pada kalangan akademisi seperti dari $\mathrm{UBH}$ (Universitas Bung Hatta), pada 3 tahun lalu yang melakukan kegiatan penanaman pohon cemara laut, hingga saat ini telah menampakkan hasil dengan hijaunya pantai sepanjang pantai pasia Tiku ini. Kegiatan lainnya adalah konservasi penyu, pengadaan rumah ikan, pembangunan penerangan di sepanjang pantai, pembangunan Aula bersama oleh UPT perikanan dan pembangunan TPI (Tempat Pelelangan Ikan). Disamping keterlibatan dari kalangan pemerintah Provinsi dan daerah, pihak NGO yang ikut mefasilitasi kawasan ini adalah pada sektor kesiagaan bencana.

Rencana ini disambut oleh Kemenpera dengan pembangunan jalan lingkar menuju pantai pasia melalui pemukiman penduduk hingga ke pantai berbentuk lingkaran, semakin mempermudah masyarakat mencapai area pantai pasia Tiku dengan nyaman. Keterilbatan masyarakat dan pemerintah tampak pada kegiatan "pesta pantai" maupun pada kegiatan harian. Pada pesta pantai, masyarakat 
telah bekerjasama membentuk tim panitia, pengatur dan pelaksana kegiatan berdasarkan kesepakatan bersama yang didukung oleh banyak departemen seperti polda, polisi air, marinir, DKP (Departemen Kelautan dan Pantai), BNPPB, PolAir, ninik-mamak, AiRut dan lainnya. Koordinasi ini dilakukan oleh walinagari, kecamatan dan bupati sebelum 15 hari menjelang acara dimulai.

Berdasarkan hasil wawancara dengan salah serorang isteri nelayan, Karmani yang memiliki 3 orang anak. Sebagai istri tukang ojek di kawasan wisata ini, la bekerja tambahan sebagai penjual makanan. la memulai berjualan semenjak tanun 2011. Disamping bekerja berjualan Karmani juga bekerja sampingan sebagai pengelola dan pengering ikan. la berjualan untuk membantu ekonomi keluarga. Hasil pendapatan kotornya perhari dapat mencapai 200.000/hari. Penghasilan ini dapat membantu 2 orang anaknya sebesar Rp.30.000,- - Rp.15.000,-/ perhari.

Dengan berjuan di pantai, ia mampu meningkatkan penghasilannya $25 \%$. la berbelanja membeli barang dagangannnya sensiri dengan memakai ojek $(2 x)$ dengan biaya ongkos (Rp.20.000,-). Untuk kebutuhan sehari-hari, kadang la menggunakan bahan jualannnya sendiri.

pantai $\begin{array}{rrr}\text { Kunjungan wisatawan ke } \\ \text { pasia ini sangat }\end{array}$ menguntungkannya, dan masyarakat nagari. Meskipun la tidak terlibat langsung dalam kegiatan pembangunan pantai, tapi la selalu mengikuti perkembangan masyarakat pantai setiap hari. Informasi selalu la peroleh dari masyarakat dan pengunjung daganagannya seputar informasi perkemabangan pantai itu sendiri.

Partisipasi masyarakat telah menetapkan 3 kesepakatan besar untuk meningkatkan pelayanan dan kunjungan wisatawan ke kawasan ini, yaitu: pelayanan seramah mungkin, satu senyum menyenangkan, standar harga,

perbedaan harga memberikan kerugian untuk berpuluh pedagang dan beratus hari bagi masyarakat sekitar dan sampah harus dibersihkan. Bantuan yang yang telah diberikan adalah penyimpanan tempat sampah, namun belum memadai serta belum adanya pengelola sampah (pembersih lingkungan).

\section{H. KESIMPULAN DAN SARAN 1. Kesimpulan}

$\mathrm{P}$ embangunan poros maritim dengan mengembangkan wisata bahari di Indonesia harus memanfaatkan Indonesia sebagai Negara Maritim. Potensi maritim ini memiliki prospek besar, salah satunya dalam wisata bahari, sehingga sangat menguntungkan kedepan apabila pariwisata bahari di Indonesia dapat dikembangkan dengan baik dan professional. Provinsi Sumatera Barat oleh Departemen Kebudayaan dan Pariwisata telah ditetapkan salah satu dari lima daerah di Indonesia yang dijadikan sebagai daerah destinasi unggulan serta menawarkan Mentawai sebagai lokasi selam terbaik Indonesia. Kebijakan ini ditetapkan oleh pemerintah pusat sebagai upaya mengembangkan pariwisata di luar pulau Jawa dan Bali.. Hal ini merupakan kesempatan untuk mengembangkan dan mempromosikan potensi wisata, khususnya wisata bahari atau kawasan pesisir yang terdapat di Sumatera Barat. Kawasan pesisir Sumatera Barat memiliki potensi yang luar biasa dan prospek untuk dikembangkan. Selain kekayaan laut yang masih belum tergarap dengan optimal, kawasan-kawasan ini memiliki objek wisata yang bisa dikembangkan secara luas.

Kesadaran dan pemahaman mereka terhadap pentingnya melestarikan trumbu karang dan sumber daya ikan telah ada sebagai bagian dari pengembangan wisata bahari, hal ini terbukti dengan kuatnya kelompok ini yang merupakan kelompok sosial non profit oriented tanpa mengharapkan uang tapi mampu memperkuat kesatuan masyarakat bersama untuk menjaga keamanan dan kelestarian lingkungan sosial dan alam. Dalam pengembangan wisata bahari, salah satu kearifan lokal 
masyarakat nelayan di Tiku adalah pelaksanaan Pesta nelayan dan dilaksanakan selama sehari sebelum ramadhan dan di hari Senin. Hasil pesta pantai disumbangkan untuk pembangunan mesjid dan mushola. Selain itu dana pesta pantai digunakan untuk pengelolaan kebersihan. Pesta ini menggunakan dua jalur yang dan pasangi sekat sepanjang pantai, yang merupakan kawasan tertutup pada saat pesta pantai dilaksanakan bagi pengunjung. Selain itu pada pesta tersebut juga mengutamakan masyarakat setempat dengan menggratiskan masyarakat sekitar (memiliki hubungan sekampung). Partisipasi masyarakat telah menetapkan 3 kesepakatan besar untuk meningkatkan pelayanan dan kunjungan wisatawan ke kawasan ini, yaitu: pelayanan seramah mungkin, satu senyum menyenangkan, standar harga, perbedaan harga memberikan kerugian untuk berpuluh pedagang dan beratus hari bagi masyarakat sekitar dan sampah harus dibersihkan.

\section{Saran}

\section{Daftar Pustaka}

Ataupah.2004. Peluang Pemberdayaan Kearifan Lokal Dalam Pembangunan Kehutanan. Kupang.

BOBP. (Bay of Bengal Program). 1990. Helping Fisherfolk to Help Themselves. A Study in People's Participation. BOBP.

Denzim Norman K. and Yvonna S. Lincoln (ed).1994. Handbook of Qualitative Research. USA: Sage Publications.

Dinas Kebudayaan dan Pariwisata Kota Padang. 2012. Profil Wisata Bahari. Padang

Earl Babbie, 1983. The Practice of Social Research. Belmont, California: Wadsworth Publishing Company.

Kusnadi. 2005. Akar Kemiskinan Nelayan. Yogyakarta: LKiS.

Kusnadi. 2006. Filosopi Pemberdayaan Masyarakat Pesisir. Bandung: Humaniora.

Lawrence Neuman, W. 1997. Social Research Methods: Qualitative and quantitative approaches. London: Allyn and Bacon.

Lestari, Mohamad.2005. Studi Implementasi Program Pemberdayaan Ekonomi Masyarakat Pesisir (Pemp) Di Kelurahan Tanjung Mas Kecamatan Semarang Utara Kota Semarang. Dialogue, 2 (3). Pp. 1-38. ISSN 1693-8399

Notoatmojo, S. 2003. Pendidikan dan Perilaku Keesehatan. Jakarta: PT. Rineka Cipta

Nikijuluw. Victor P.H. 2001. Populasi dan Sosial Ekonomi Masyarakat Pesisir serta Strategi Pemberdayaan Mereka Dalam Konteks Pengelolaan Sumberdaya Pesisir Secara Terpadu dalam Makalah pada Pelatihan Pengelolaan Pesisir Terpadu. 
Proyek Pesisir, Pusat Kajian Sumberdaya Pesisir dan Lautan, Institut Pertanian Bogor (IPB). Hotel Permata, Bogor, 29 Oktober 2001.

Razak Miraza. 2009. Implementasi Program Pemberdayaan Ekonomi Masyarakat Pesisir (PEMP) di Kecamatan Tanjung Pura, Kabupaten Langkat. Skripsi S1 Departemen Ilmu Kesejahteraan Sosial FISIP USU. Medan. Tidak Dipublikasikan

Vredenbregt. 1983. Metode dan Teknik Penelitian Masyarakat. Jakarta: PT. Gramedia.

Zamzami, Lucky. 2011. Pemberdayaan Ekonomi Masyarakat Pesisir di Nagari Amping Perak, Sumatera Barat dalam Jurnal MIMBAR Volume XXVII, No. 1 (Juni 2011) ISSN 0215-8172, Hal. 1-124, Bandung: Unisba

Zamzami, Lucky. 2010. Efektivitas Pelaksanaan Program Pemberdayaan Ekonomi Masyarakat Pesisir (PEMP) pada Masyarakat Nelayan Buruh di Nagari Ampiang Perak, Kecamatan Sutera, Kabupaten Pesisir Selatan, Provinsi Sumatera Barat. Laporan Akhir Penelitian Dosen Muda Tahun 2010. Padang: Lembaga Penelitian Universitas Andalas. Tidak Dipublikasikan.

\section{$\underline{\text { Internet }}$}

http://komapos.com/Sumbar/Agam/5930-pemkab-agam-kembangkan-dua-pulau/17 Februari 2015

http://id. Wikipedia.org/Pengetahuan, diakses tanggal 20 April 2015 